\title{
Kosovo Nationalism and the NATO Involvement in Managing a New Crisis
}

\author{
Indrit Shtupi* \\ Arjan Vasjari \\ Xhabir Zejnuni \\ European University of Tirana \\ *Corresponding author: Cel: +355692926251/indritshtupi@yahoo.com
}

Doi:10.5901/mjss.2013.v4n10p283

\section{Abstract}

This article consists as an initial step, the chronology to the Kosovo Crisis within Kosovo Nationalism focusing on the origins of the crisis, and the failure of the diplomatic efforts. The public opinion about the Kosovo issue (Kosovar's and Serb's opinion). States are reluctant to characterize use of force in the peace-enforcement context as equivalent to military operations in other conflict environments. Furthermore, state practice does not encourage the notion that rules of international humanitarian law can be applied to peace-enforcement in a predictable, systematic manner. Nonetheless, development at the close of the 20th century point in a positive direction. Also include NATO's objectives in Kosovo. A brief background to peace operations, including peace enforcement, humanitarian intervention, the reasons standing behind the operation, its aims, justification and motives. The legality of intervention, also opinions about the NATO involvement in Kosovo.

Key words: Nationalism, crisis, NATO, intervention, credibility, peacekeeping, peacemaking, independence.

\section{Introduction}

The millennium just past offers a useful historical context for lawyers, soldiers and policy makers who have to plan and conduct peace-enforcement, peacekeeping missions. There has been an unspoken assumption about peaceenforcement operations. They are thought to be so unlike traditional wars that they cannot be accommodated within an easily acquired framework of international humanitarian law. Any differences that may separate peace-enforcement from other conflict-related military operations are, however, not profound and should not deny peace enforces access to rules of international humanitarian law. (Totten, S. 2007.Pg. 797)

Events during the Kosovo bloody conflict, and after, demonstrate that rules for interventional-armed conflict (NATO intervention in our case) are beginning to take form.

Operation Allied Force in Kosovo was widely discussed not only from a legal, but also from a political and a moral perspective. Not undermining moral or political considerations - which as will be described later, played a vital part in the discussion on NATO intervention - the focus of this topic is put on the assessment of the legal dimension of the operation.

The new context of conflict has impacted greatly upon all peacekeeping endeavours and increased the need for more far reaching peacekeeping missions. While such missions have therefore increased in size, frequency and complexity, little improvement to practice has been witnessed.

\section{Kosovo Nationalism}

\subsection{Chronology of Kosovo Crisis}

On 23 March 1989, the provincial assembly of Kosovo, under unusual circumstances (with tanks and armored cars in front of it), passed the constitutional amendments. On 28 March the Serbian Assembly in Belgrade voted the final confirmation of the amendments. Kosovo's autonomy was reduced to a mere token (Von Kohl, Ch. and Libal, W.1989. pg.116). With the votes of Serbia, Kosovo, Vojvodina and Montenegro in his pocket, Milosevic would gain a controlling majority on federal presidency. This new environment of nationalist politics combined with the Croatian nationalism and 
the increasing fear of Slovenia leaderships lead unavoidably to the final break-up. Meanwhile, in Kosovo major protests, violent clashes and riots took place in at least nine towns.

On $2^{\text {nd }}$ July 1990, 114 out of the 123 Albanian members of the Assembly did meet in the street outside the lockedup Assembly building, and passed a resolution declaring Kosovo "and equal and independent entity within the framework of the Yugoslav federation". In response, the Serbian authorities dissolved both the Assembly and the government. Many of the Albanian delegates who had taken part on the $2^{\text {nd }}$ July resolution held another meeting in the town of Kacanik on 7 September, in conditions of great secrecy. There they agreed on the proclamation of a constitutional law for a "Republic of Kosovo". On 24 May 1992 elections were held in Kosovo - in conspiracy, using private houses as polling - stations in order to create a new republican assembly and government.(Daily Telegraph, 25 May 1992) In the late 1980s two intellectual organizations played a very important political and cultural role among the Kosovo Albanians: The Association of Writers of Kosovo and the Association of Philosophers and Sociologist of Kosovo. The Association of Writers of Kosovo presented a statement of Albanian national political aims, which attracted wide support within Kosovo. Its president Dr. Ibrahim Rugova became the leader of the political movement "Democratic League of Kosovo"- LDK which was officially founded in December 1989. The shadow assembly of 1992 elected Rugova President of the Kosovo Republic. (Maliqi, Sh. 1997. pg. 144)

The basic policy pursued by Rugova and the LDK since 1990 was: to prevent violent revolt, to "internationalize" the problem; and to deny systematically the legitimacy of Serbian rule, boycotting elections and creating the outlines of the states apparatus of Kosovo Republic.

The outbreak of war in former Yugoslavia in the summer of 1991 initially had little effect in Kosovo apart from the refusal of Kosovo Albanians to do their military service in Yugoslav (Serbian) army. (Verli, M. 2002. pg. 355)

The position of Albanians in Kosovo worsened with the launching of war in Bosnia in April 1992. The rhetoric Of Serbian nationalism was focused on the Islamic "threat", "demographic aggression" (high birth-rate) of Bosnian Muslims (terms used in Kosovo) and the threat of "Islamic crescent" extending from Bosnia through the Sandzak to the Muslim Albanian in Kosovo.

The ending of war in Bosnia did not bring end to the crisis in Kosovo, consequently it was a blow to the Rugova's prestige. The settlement of Dayton (Ohio, November 1995) left the Kosovo as it was. The only measures taken about Kosovo was an agreement by Un Security Council that the sanctions against Serbia would remain until Belgrade reformed its human rights record in Kosovo. The only serious challenge to Milosevic came not from the West (the western diplomat expressed their gratefulness for his "peacemaking" efforts and regarded him as a constructive force in the region) but from his own internal opposition, which mounted a lengthy series of popular street-protests during the winter of 1996-1997. At the same time, the criticism of Rugova's policy within the political circles took two forms: some argued that his absolute refusal to negotiate with Belgrade was unrealistic, others wanted a more active policy of protests. This was an expression of popular frustration at the inability of Rugova to gain a new recognition of Kosovo's interests in the aftermath of Dayton (Baleta, A. (1999) "Kosovo: From Dayton until Rambouillet", SH.B Koha Tirana;pg. 48).

Two others factors also contributed to the weakening of Rugova`s position:

1. One was the political crisis in Albania in the spring1997, where, after the failure of pyramid schemes, an insurrection broke out which aimed at the overthrown of Sali Berisha. Berisha had given moral and political support to the LDK (the only government that that recognize the Kosovo republic). Any post-Berisha government would be less willing to aid the Kosovo Albanians.

2. The second factor was the appearance in summer of 1997 of the "Kosovo Liberation Army". Its spokesman gave interviews in Switzerland in which he declared that the KLA was responsible for several recent attacks of Serb policeman and that "this is the movement of people now". (New York Times International, 11 May 1997) As the Albanians became frustrated with the Rugova strategy and immediately after the events of 22 April 1996(the first attack of KLA - three Serbs murdered in Decani) Adem Demaqi (one of Rugova's harshest critics) noted that Kosovo Albanians were "increasing vociferously accusing their leaders of betraying national interests. (Malcolm, N. 1998. pg.7)

Meanwhile, the Serbian opposition parties argued that the boycott of Serbian elections helped Milosevic to maintain his grip on the country as the Serbian minority in Kosovo, 10 percent of the province's population, delivered all the parliamentary seats to Milosevic and his allies.

On Thursday 5 March 1998, a large force of Serbian police launched an offensive in Drenica, killing 22 Albanian fighters. The assault occurred three weeks before elections called by Rugova to Kosovo`s unofficial government. This 
last event had three consequences: KLA became stronger, Western Europe and US stepped up the involvement in the conflict and the regional stability was again unsettled. (Glenny, M. 2000. pg. 652).

On 9 March the Contact Group (USA, Russia, Britain, France, Germany and Italy) threatened a limited package of sanctions, such as visa restriction and the blocking of investment credits if Milosevic did not change his policy within two weeks (it was extended by another month). Meanwhile a resolution of the UN Security Council had imposed an arms embargo, aimed at cutting off supplies to both Yugoslavia and the KLA. The West for many reasons (as the dangerous of Greater Albania) refused to support the KLA`s goal of independence. What the international community insisted for was the extensive autonomy that would be guaranteed with the presence of a NATO peacekeeping force. At the end of September 1998 world opinion was shocked by the discovery of a massacre near the village Obrinje in central Kosovo. On 16 October the US envoy Richard Holbrooke finally persuaded Milosevic to sign an agreement that included: a promise to scale down the Serbian Deployment in Kosovo to its pre-February level, an agreement that all Kosovar refugees could turn back to their homes, and an acceptance of the presence of international observers to make sure the implementation of the agreement. The next two months a major reduction of fighting was observed and the Verification Mission began to operate.

In mid-January 1999 the Western diplomacy was shocked by another event: the discovery of a massacre at the village of Racak, were 45 Albanian civilians, including children, had been murdered. When the head Verification Mission condemned this atrocity, the Belgrade demanded his removal and also they refused entry to the chief prosecutor of the International War Crimes Tribunal. Two weeks later the Contact Group announced the convocation of Serbian and Albanian leaderships to a conference at Rambouillet, near Paris, on 6 February 1999. The aim of this conference was to reach an agreement on the political future of Kosovo. The plan consisted of a detailed set of constitutional arrangements for an autonomous Kosovo, including: elected Assembly, a President and a Constitutional Court. The most important part of this plan was the so-called "Interim Agreement" which anticipated that "Three years after the entry into force of this Agreement, an international meeting shall be convened to determine a mechanism for a final settlement for Kosovo, on the basis of the will of the people....". (Qosja, R. 1999. fq.32)

On 18 February the Albanian (inconclusive negotiation when objections, oppositions and "conditions" followed) representatives finally signed the agreement, whereas the Yugoslav delegation declared its continuing opposition to the plan.

Meanwhile, within Kosovo the Serbian military forces under the direction of General Nebojsa Pavkovic, and the paramilitary forces known as "ethnic cleaners", controlled by notorious gangster "Arkan" were established in Kosovo. Their deployment was in accordance with a strategic plan known as "Operation Horseshoe" aimed at "solving" the Kosovo problem.

As the Western defensive alliance approached its $50^{\text {th }}$ birthday celebration in April 1999, it was confronted with a dilemma. It must begin a war against a sovereign country of 8 million inhabitants or back down its public commitment to do so, in the event of Milosevic refusing the Rambouillet agreement. "The only alternative to shooting yourself in the foot", Carl Bildt told White House staff ten days before the bombing started, "it no do it". The reply came back: "Credibility".

On 24 March 1999, after the failure of one more attempt at negotiation by Holbrooke and a final rejection of Rambouillet proposal by the Serbian parliament, NATO forces began their campaign of air strikes against strategic targets inside Yugoslavia.

\section{NATO Involvement in Kosovo}

\subsection{Objectives of NATO in Kosovo}

When NATO launched its air campaign, the situation in Kosovo was one of rising ethnic violence, suppression of democracy, a breakdown of law and order, systematic human rights abuses by the ruling authorities and a refusal by the Belgrade government to seek, or accept a political solution. At the same time, there was evidence that the government of the Federal Republic of Yugoslavia was planning to escalate its campaign of repression. The international community could see a humanitarian disaster looming.

In December 1997, NATO foreign ministers confirmed that NATO's interest in stability in Balkans extended beyond Bosnia Herzegovina to the surrounding region and expressed concern at the rising ethnic tension in Kosovo. (www.transnationl.org/pressinf/pf74html) 
It is important to recall the enormous effort made by the NATO and the international community to avoid military intervention over Kosovo, while making clear to President Milosevic its ultimate preparedness to use force, if necessary.

In the spring of 1998, NATO ministers called on all parties to seek a peaceful resolution to the crisis, while directing the Alliance's military authorities to prepare options for the use of force, should it prove necessary.

NATO's objectives in relation to the conflict in Kosovo were set out in the Statement issued at the Extraordinary Meeting of the North Atlantic Council held at NATO on 12 April 1999 and were reaffirmed by the Heads of State and Government in Washington on 23 April 1999:

- a verifiable stop to all military action and the immediate ending of violence and repression;

- the withdrawal from Kosovo of the military, police and paramilitary forces;

- the stationing in Kosovo of an international military presence;

- the unconditional and safe return of all refugees and displaced persons and unhindered access to them by humanitarian aid organizations;

- the establishment of a political framework agreement for Kosovo on the basis of the Rambouillet Accords, in conformity with international law and the Charter of the United Nations. (www.sane-boston.org/ articles/saneandpress/objectives.html)

Throughout the conflict, the achievements of these objectives, accompanied by measures to ensure their full implementation, has been regarded by the Alliance as the prerequisite for bringing to an end the violence and human suffering in Kosovo.

\subsection{NATO Operation in Kosovo}

On 24 March 1999, NATO started Peace-enforcement actions based an air campaign against the Federal Republic of Yugoslavia. The air campaign began with strikes on air defenses across the FRY and a limited rage of military targets in Kosovo and elsewhere in southern Serbia. In late March, when Mlilosevic showed no sign of responding to the opening phase, the range of attacks was widened to cover carefully selected targets of high military value across the FRY. Targeting policy was under political control both in NATO and nationally. Within NATO, SACUER consulted the Secretary General closely throughout the campaign to ensure that the target selection process took proper account of the political direction given by the NAC. All UK targets were cleared nationally for compliance with international law. NATO was successful in a way unprecedented in previous campaigns in keeping to a minimum collateral damage or civilian casualties. In contrast to Milosevic's forces operation in Kosovo, we were not out to attack the people of Serbia. (kosovo.mod.uk/account/nato.htm).

Sadly, there were tragic incidents. The mistaken strike on the Chinese Embassy, the destruction of a train which crossed the bridge during a an aerial attack, and the death

of some Kosovar civilians in NATO air strikes against Korisa are three examples but the noteworthy thing is that there were so few in relations to the size of campaign. In each case NATO investigated the cause and made public as much of the detail as possible and as soon as possible. This open approach contrasted starkly with Milosevic's propaganda and distortion.

The campaign aimed to force the Serbian side to accept the Rambouillet agreement and thus, to prevent an imminent humanitarian catastrophe. Serbia inevitably saw any such arrangements as an unacceptable violation of its territorial integrity and sovereignty. (Wyman, M. (1999). Kosovo "The Politics of Delusion"; Why Intervention Was Right? pg. 105). For the Serbian government, the mantras of sovereignty and territorial inviolability, and myths about Kosovo's centrality to the Serbian nation, as well as the domestic political climate, made this impossible. NATO accepted that it would take only a few days to bring the Belgrade government to the fold. Instead, a military operation continued for 11 weeks before the war came to an end. (www.int/kosovo/all-frce.html). Serbian military and paramilitary forces reacted with extreme violence against KLA fighters and the ethnic Albanian civilian population. Altogether, more than 800.000 people were displaced and thousands killed. After the G-8 states had agreed on the text for UN Security Council Resolution that was also acceptable to the FRY, on 9 June 1999 representatives of the Yugoslav military and NATO concluded a military-technical agreement on the withdrawal of Yugoslav troops from Kosovo. This ended the war. 


\subsection{The Legal Context of NATO intervention in Kosovo}

\subsubsection{The Legality of Intervention}

In international law, maters are relatively clear. States shall no intervene in the internal affairs of a State or in matters that are essentially within domestic jurisdiction of a State (Article 2 of the Charter of the United Nations). Nonetheless, there is an exception to this rule: the Security Council may intervene as it sees fit when it determines that there is a threat to international peace and security, which authorizes it to take enforcement action under Chapter VII of the Charter (Art 2(7) of the UN Charter).

In legal terms, NATO, as a regional arrangement (which it is in reality because of the terms of the Washington Treaty) or regional agency (which is what the OSCE is, since the 1993 framework agreement between that organization and the UN, but what NATO cannot claim to be), may intervene in respect of international peace and security, provided that the actions it undertake are consistent with the Purposes and Principles of the UN (Article 52) but Article 53 is also extremely clear: "no enforcement action shall be taken under regional arrangements or by regional agencies without the authorization of the Security Council".

Most legal experts agree that under that provision, the air strikes against Serbia were illegal, because the Security Council never authorized them. Other, more libertarian experts cite humanitarian law or the law of "collective emergency" to justify NATO`s action. (Paust, J. J. 1999. Vol 33, No.9) The UN Secretary-General, Kofi Anan, has himself acknowledged that the

NATO action was legitimate, and has gone so far as to say that a new norm of intervention was now emerging for cases involving the violent repression of minorities that will and must take precedence over the other concerns of the law of States. Thus any flagrant violation of humanitarian law, be it crimes against humanity, violations of human rights or the Geneva Conventions, or ethnic cleansing, may provide a legitimate basis for action on the part of the international community because all these issues have international consequences and go well beyond the sacrosanct principle of the domestic jurisdiction of States. (Conlon, P. 1999. vol.33, No. 9) The real dilemma therefore lies in the fact that "while the Carter was a head of its time in 1945, the reverse is true today", because the world has evolved to the point that it has entered a post-Westphalia era in which humanitarian law is just as compelling as the law of treaties freely entered into by States. There are thus experts who believe that if the Security Council is in capable of acting, a new norm of intervention by a coalition of States would seem to be entirely justified were large-scale atrocities are being committed.

That being said, the legal debate has not yet been resolved because any interpretation based on the right to intervene in the name of humanitarian law is improper in two respects. First, it amounts to striping the veto of the major powers of any substance, or nullifying the veto; second it creates intolerable precedent in that it means that a group or coalition of States may now, with no formal authorization from the Security Council, act as it pleases, citing the precedent of Kosovo.

The legal debate is therefore not over. While NATO's action was not illegal under the principles of international law, the question remains of whether the concept of "humanitarian emergency" marks a turning point in the evolution of international humanitarian law. As history and events to come in Kosovo unfold, they will undoubtedly one day provide the answer to the question of whether the world has entered a new era in international relations - a "post-Westphalia plus" era - or not.

\subsubsection{Law and Morality}

Whether NATO action was lawful is a very different question from whether NATO action was right. Pointed out that there is a moral, as well as a legal issue at stake:

"Humanitarian interventions involving the threat or use of armed force and undertaken without the mandate or the authorization of the Security Council will, as a matter of principle, remain in breach of international law. (Krieger, $\mathrm{H}$. 2001.pg. 402)

But such a general statement cannot be the last word. Rather, in any instance of humanitarian intervention a careful assessment will have to be made on how heavily such illegality weighs against all the circumstances of a particular concrete case, and of the efforts, if any, undertaken by the parties involved to get 'as close to the law' as possible. Such analyses will influence not only the moral but also the legal judgment in such cases". 
Under international law, countries can intervene in the internal affairs of a sovereign nation under two conditions: first, the nation must be brutally abusing human rights and second, legitimate international authorities must authorize the intervention. Some critics of intervention question whether Serbian abuses were sufficiently sever to warranted intervention and argue that NATO needed to receive authorization from the United Nations Security Council. Others criticize the selectivity of the West's moral outrage, citing even worse abuses in Southeastern Turkey (against the Turks), the Sudan, Rwanda, and Chechnya.

While upholding the importance of the rule of law, and clearly discomforted by some aspects of the legality of the Kosovo campaign, pointed to US Supreme Court Justice Holmes's dictum that "a constitution is not a suicide pact". We believe that, while legal questions in international relations are important, law cannot become a means by which universally acknowledged principles of human rights are undermined.

The determine whether NATO's action was morally justified, and legally justified under the criteria which NATO set itself. We have to ask whether a humanitarian emergency existed before NATO intervened, and whether a humanitarian catastrophe would have occurred perhaps over a number of years, rather than being concentrated within the 78 days of the NATO campaign if intervention had no taken place. We have dealt with these issues elsewhere, and conclude that the answer to both questions is "yes". That being the case, we conclude that NATO's military action, if of dubious legality in the current state of international law, was justified on moral grounds. (www.publcations.parlament.uk)

\subsection{Public Opinion about NATO Involvement in Kosovo}

\subsubsection{Was NATO Successful?}

What follows, then is a documentary analysis, examining NATO successful issue by public opinion on all ideological sides of the debate, in order to help our preconceptions. It is necessary to examine the two dominant opinions of those opposed to NATO intervention.

The first, and perhaps most widely articulated, argument holds that NATO intervention in Kosovo was illegal (Clausson, M.I. 2006. Pg. 3), as it by-passed the UN Security Council in not obtaining that body's approval. In this, they claim that the Security Council is the only international body competent to authorize intervention on humanitarian or other grounds.

In the second instance, many have argued that NATO's intervention was illegal as it constituted an attack on a sovereign state on the basis of that state's domestic problems, thereby violating its territorial integrity. This, they claim stems from Articles 2 and 4 of the UN Charter, prohibiting the use of the force against the territorial integrity or political independence of any state (This is the Serbian perspective). These arguments tell us that the NATO intervention in Kosovo was not successful.

But we have to presentate and the Kosovo perspective. From the perspective of Kosovo Albanians both before, during, and after then action in question, NATO's intervention on behalf of those threatened with, and subject to, ethnic cleansing, was legal and successful for a variety of reasons rooted in law and history. Not only did it rectify an historical injustice committed by the Great Powers at the London Conference of 1913, in which Serbia was granted possession of the occupied territory of Kosovo, but it recognized the declaration of sovereignty of the Kosovo people in 1943 and 1944, which was, in fact, backed by Yugoslav leader Josiph Broz Tito.

Furthermore, the 1974 Constitution of the Socialist Federal Republic of Yugoslavia constituted Kosovo as one of eight federal units including rights to judicial and legislative autonomy and representation of the federal level independent of Serbian authorities making it a Republic in everything but name, status illegally revoked by the Serbia with the connivance of federal politicians fearful of Serbian disruption.

The NATO intervention was successful because the intervention was legalized on the basis of international instruments and declarations. (www.washingtonpost.com/wp-srv/ inatl/ zforum/ 99/ dowling041999.htm). The legal context of NATO intervention in Kosovo we will see further down.

\subsubsection{NATO Credibility}

Ultimately, NATO's credibility, in line with the demands of deterrence theory during the Cold War, was paramount. With Alliance credibility on the line, the logic of the situation was such that the Allies would have to take action if the KLA signed the agreement and Belgrade did not. To demonstrate this and to reinforce the links with the situation in Bosnia Herzegovina, resolve was shown in the period before Kosovo talks resumed in mid-March by international action that 
saw Bosnian Serb President Nikola Poplasen sacked for failure to cooperate in peace implementation and the town of Brcko, strategically vital to Serbian notions of Bosnian Serb statehood, removed from Republika Srpska's control and given separate status under joint local administration. This was also the kind of situation in which further apprehension of war crimes inductees might be expected. Action regarding Bosnia and Herzegovina was a signal of similar resolve over Kosovo. (www.journal.forces.gc.ca/).

The dangers in NATO's not showing resolve, both regarding the message sent to the parties in the former Yugoslav lands and in the wider world about NATO credibility, as well as the potential damage to transatlantic relations of failure to act, meant that the Alliance had no option but to act, if the circumstances required it. The same logic applied to the question of the committing a ground force to implement an agreement, (Schnabel, A., Thakur, R. Ch. 2000. Pg. 3). whether reached with or without coercive air action. NATO`s credibility regarding the parties, its image, and standing in international eyes, and its meaning and value as a vital asset and interest of its members meant that the 28.000-strong force envisaged by plans would need to be deployed, not only to assist peace in Kosovo, but to ensure that the vital interest of each member in maintaining Alliance strength was met.

\section{Conclusion}

The humanitarian catastrophe in Kosovo and the NATO intervention is a precedent of considerable promise for the Balkan region and for many other parts of world afflicted with endemic communal violence.

The legality of Kosovo intervention still is a controversial issue and the majority of lawyers agree that the operation was not legal under the UN Charter framework. Nevertheless, the same lawyers often justify the action on political and moral grounds. The lessons, which may be drawn from the Kosovo crisis, include the phenomena of "hard cases in which terrible dilemmas must be faced and imperative political and moral considerations may appear to leave no choice but to act outside the law.

The fact that a respected authority in international law, admits that in certain instances it is accepted to act outside the law, should force us to think whether indeed existing law reflects the need to protect human rights in the case of humanitarian catastrophe. This can lead us to the conclusion that the emerging doctrine of humanitarian intervention, which can be justified on moral or political grounds, should be turn into a legal doctrine of humanitarian intervention. This requires either changing the UN Charter framework or allowing for its more flexible interpretation. One should however not be naive enough to believe that this will be a rapid process. It seems yet that the Kosovo intervention can be treated as a significant precedent that will have a vital impact on the gradual process of creating a legal doctrine of humanitarian intervention.

Finally, whenever possible, NATO should threaten or use force with the full backing of the international community, as expressed by the UN Security Council. It did so in Bosnia. The draft of Rambouillet agreement for Kosovo stipulated that the UN be invited to endorse a NATO-led peace operation to support its implementation. But the Alliance cannot be held hostage to the dictates of non-NATO members. As an alliance of democratic states acting by consensus, NATO must preserve the possibility of acting without specific UN authorization. Even then, the allies should base their action on appropriate legal instruments, including the UN charter and, for actions in Europe, the Helsinki Final Act and the Charter of Paris.

Moreover, the question can be raised: what would have happened if the NATO did not intervene in Kosovo?

In response to the new context of conflict, peacekeeping missions have been expanded to include the disciplines of peacemaking and peace building. While peacekeeping aims to provide an environment of stability to facilitate the processes of

both reconstruction and progress toward peace, peace-making is a diplomatic and political endeavour applied strategically to confrontation situations, through such undertakings as mediation and negotiation, in order to arrest the conflict or at least prevent it from escalating. The securing of human rights, the facilitation of elections, the support given to attempts at political reconciliation and new modes of governance.

\section{References}

Totten, S. (2007). "The Prevention and Intervention of Genocide: An Annotated Bibliography".

Von Kohl, Ch. and Libal, W. (1989). "Kosovo".

Daily Telegraph, 25 May 1992.

Maliqi, Sh. (1997). "Albanian Movement of Kosova".

Verli, M. (2002). "Kosovo in the focus of history" vol. 2 Tirana. 
New York Times International, 11 May 1997.

Malcolm, N. (1998). "Kosovo-A Short History".

Glenny, M. (2000). "The Balkans Nationalism, War and the Great Powers 1804-1999", London.

Qosja, R. (1999) "Bloody Peace, International Conference for Kosovo, Rambuillet". Tirana.

Wyman, M. (1999). Kosovo "The Politics of Delusion"; Why Intervention Was Right?

Paust, J. J. (1999). "NATO Use of Force in Yugoslavia" in United Nations Law Reports, Vol 33, No.9.

Conlon, P. (1999). "This Dilemma is No Accident", United nations Law reports, vol.33, No. 9.

Krieger, H. (2001). "The Kosovo Conflict and International Law: An Analytical Documentation 1974-1999".

Clausson, M.I. (2006). "Understanding the War in Kosovo".

Schnabel, A., Thakur, R. Ch. (2000). "Kosovo and the Challenge of Humanitarian Intervention".

\section{Internet Sources}

www.transnationl.org/pressinf/pf74html

www.sane-boston.org/articles/saneandpress/objectives.html

kosovo.mod.uk/account/nato.htm

www.int/kosovo/all-frce.html

www.publcations.parlament.uk

www.washingtonpost.com/wp-srv/ inat// zforum/ 99/ dowling041999.htm

www.journal.forces.gc.cal 